\title{
Comparison of 3 Medicine Groups Used to Control Glycemic and Glycated Hemoglobin Levels in Newly Diagnosed Type 2 Diabetes Patients
}

\author{
Ngoc Chau Nguyen ${ }^{1}$, Hoai Thuong Pham², Diep Thao Pham ${ }^{3}$, Thi Minh Hoang ${ }^{1}$, Thi Phuong Lan Dam¹, Thi Hang Ho ${ }^{1}$, Duy \\ Quy Dang ${ }^{1}$, Nhu Binh Do ${ }^{1}$, Quang Thuan Huynh ${ }^{1 *}$
}

${ }^{1}$ Military Hospital 103, Ha Dong, Ha Noi, Viet Nam; ${ }^{2}$ Quang Ninh Medical College, Quang Ninh, Vietnam; ${ }^{3}$ Viet Duc Hospital, Ha Noi, Viet Nam

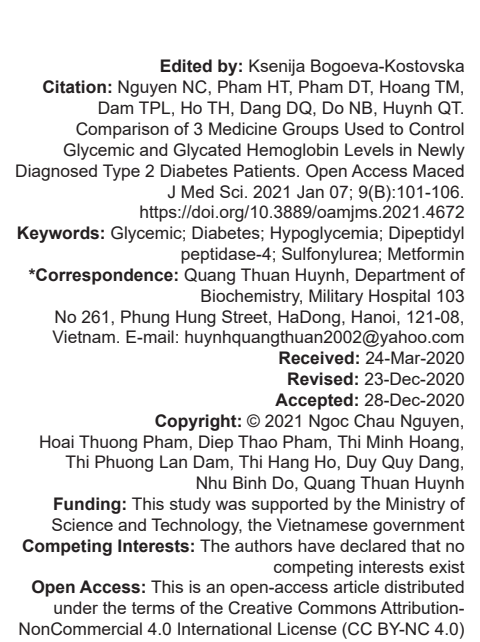

\section{Abstract}

AIM: This research aims to compare the effectiveness of three medicines groups in controlling glycemic and glycated hemoglobin (HbA1c) levels in the newly diagnosed diabetes mellitus type 2.

METHODS: One hundred fifty newly diagnosed patients with type 2 diabetes were treated by mono therapy and divided into three groups. Each group of 50 patients was treated by one medicine: Group 1 using Diamicron MR $30 \mathrm{mg}$ (Sulfonylurea) - three capsules per day, Group 2 using metformin $500 \mathrm{mg}-1-3$ capsules per day, and Group 3 using Januvia (sitagliptin, dipeptidyl peptidase-4 inhibitor) $100 \mathrm{mg}-1$ capsule per day. The evaluation of glucose control was based on fasting plasma glucose and $\mathrm{HbA} 1 \mathrm{c}$ concentration and divided into three levels: Excellent, good, and poor. The assessment was carried out after every 3 months of treatment, at $3^{\text {rd }}$ month, $6^{\text {th }}$ month, and $12^{\text {th }}$ month (WHO, 2002).

RESULTS: After treatment 3, 6, and 12 months, glucose level was decreased when compared to before treatment in all three groups $\left(p_{\text {all }}<0.001\right)$. At the month $6^{\text {th }}$, the groups treated by sulfonylurea and sitagliptin had lower glucose level than metformin (with $p$ values were 0.04 and 0.01 , respectively), and maintained the low glucose level from the month $6^{\text {th }}$ to month $12^{\text {th }}$ (with $p$ values were 0.71 and 0.77 , respectively) while glucose level of the metformin group increased $(p=0.005)$. HbA1c has decreased dramatically in all three groups after treatment ( $p$ values of sulfonylurea group at the month $3^{\text {rd }}, 6^{\text {th }}$, and $12^{\text {th }}$ vs. before treatment were $0.006,0.021$, and 0.001 , respectively; all $p$ values of metformin group at the month $3^{\text {rd }}, 6^{\text {th }}$, and $12^{\text {th }}$ vs. before treatment were below 0.001 ; all p values of sitagliptin group at the month $3^{\text {rd }}, 6^{\text {th }}$, and $12^{\text {th }}$ vs. before treatment were below 0.001 ). The group treated by sitagliptin got the highes ratio of excellent $\mathrm{HbA} 1 \mathrm{c}$ control (82\% after 12 months of treatment).

CONCLUSION: Significant improvement of glucose and HbA1c levels was observed in all three groups. Glucose control level of group treated with sulfonylurea was markedly improved and the group treated with sitagliptin achieved optimal control of $\mathrm{HbA} 1 \mathrm{c}$.

\section{Introduction}

Diabetes mellitus type 2 is a noninfectious chronic disease with tendency for rapid increase in observed numbers of patients worldwide. The metabolic disorder in diabetes mellitus is characterized by high glucose concentration which is caused by absolute or relative insulin deficit. Prolonged hyperglycemia causes functional disorders and failure in many organs especially eyes, kidney, neural system, and vascular system [1].

The treatment target is to control strictly blood glucose concentration, glycated hemoglobin ( $\mathrm{HbA} 1 \mathrm{c})$, vascular risk, and lipid disorder. If the $\mathrm{HbA} 1 \mathrm{c}$ level is normal, the risk of cardiovascular is decreased [2]. However, about $50 \%$ patients with diabetes achieve the target of $\mathrm{HbA} 1 \mathrm{c}$ control level after treatment [3].

All the therapy for diabetes achieves the same target. This is necessary for excellent glycemic control to reduce the complications. In recent years, the number of medicines used for treating diabetes has been increased. However, the treating strategy is not only to reduce the original glycemic level but also to maintain over time by many different mechanisms because of high efficacy, decreasing the risk of hypoglycemia, low cost [4].

The latest therapy option for initial monotherapy recommended by the American Diabetes Association and the European Association for the Study of Diabetes was using metformin for newly diagnosed patients [5]. Others medication for lowering such as dipeptidyl peptidase-4 (DPP-4) inhibitors or sulfonylureas nowadays had their later generation (sitagliptin, Diamicron,...) with lower complications and more safety [5], [6], [7], [8].

The main purpose of this study is to evaluate the effect of control in newly diagnosed type 2 diabetes (nT2D) patients treated by metformin, Diamicron, and sitagliptin as monotherapy. 


\section{Materials and Methods}

\section{Study design and participants}

A cross-sectional study was conducted on the nT2D patients in Quang Ninh Province Hospital from 5/2017 to 4/2019. A total of 150 T2D patients were recruited and randomized in an equal ratio into three groups. Eligible participants were all adult and first diagnosed diabetes mellitus type 2 (based on International Diabetes Federation, IDF criteria 2004). All of participants had not been treated by any kinds of drugs that affect to glucose blood such as thiazide diuretic, corticosteroid, and estrogen contraceptive. Exclusion criteria were pregnancy, cancer, nephritis, nephritic syndrome. Each group of patients has been treated by one group of medicine: Group 1: Sulfonylurea (Diamicron $30 \mathrm{mg} \times 1-3$ tablets/day); Group 2: Metformin $500 \mathrm{mg} \times 1-3$ tablets/day; and Group 3: Sitagliptin (Januvia $100 \mathrm{mg} \times 1$ tablet/day).

\section{Measurements}

The blood samples were collected at four points of time: Before treatment, after treatment of 3 months, 6 months, and 12 months. The plasma was collected and stored at $-20^{\circ} \mathrm{C}$ to test glucose, $\mathrm{HbA} 1 \mathrm{c}$ in Military Hospital 103. Glucose blood level was examined by hexokinase in AU 5800 (Beckman coulter, US) and HbA1c level was examined by HPLC in Premier 902 (Trinity Biotec, US). Based on the guideline of $\mathrm{WHO} 2002$, the guideline of IDF for managing T2D primary care 2017 and guideline of ADA 2020, glycemic control was classified by three levels (excellent ranging from 3.9 to $6.5 \mathrm{mmol} / /$; good ranging from 6.5 to $7.5 \mathrm{mmol} / \mathrm{l}$, and poor ranging upper than $8 \mathrm{mmol} / \mathrm{l})$ based on fasting glucose plasma and $\mathrm{HbA} 1 \mathrm{c}$ percentage was divided into three level (excellent with $\mathrm{HbA} 1 \mathrm{c} \leq 6.5 \%$; good with $\mathrm{HbA} 1 \mathrm{c}$ ranging from $6.6 \%$ to $7.5 \%$, and poor with $\mathrm{HbA} 1 \mathrm{c}>7.5 \%$ ) [9], [10], [11].

\section{Statistic analysis}

We used Stata 12.0 statistic software for Windows. The glucose and $\mathrm{HbA} 1 \mathrm{c}$ levels were parametric numbers and presented by mean and standard division. We used a t-test to compare the mean of glucose and $\mathrm{HbA} 1 \mathrm{c}$ concentration of all groups. The effect of plasma glucose and $\mathrm{HbA1c}$ control was presented in percentage. The percentage of each level (excellent, good, and poor) was equaled to the division of the numbers of that level in each group and the total number of patients in a group (50 patients).

\section{Ethical statement}

All participants were dispensed with written informed consents, and the study was approved by the
Ethical Committee of Military Medical University, Hanoi, Vietnam (No: 68/2017/QĐ-HĐĐĐ date 28 month 4 year 2017). The study was also conducted using good clinical practice following the Declaration of Helsinki.

\section{Results}

\section{Characteristics of study participants}

The characteristics of study population were described more details in Table 1.

Table 1: Characteristics of patient participants

\begin{tabular}{llll}
\hline Variables & Sulfonylurea & Metformin & Sitagliptin \\
\hline Age, $\mathrm{n}(\%)$ & $50(100)$ & $50(100)$ & $50(100)$ \\
$20-39$ years, $\mathrm{n}(\%)$ & $1(2)$ & $1(2)$ & $4(8)$ \\
$40-59$ years, $\mathrm{n}(\%)$ & $15(30)$ & $17(34)$ & $22(44)$ \\
$60-79$ years, $\mathrm{n}(\%)$ & $32(64)$ & $30(60)$ & $23(46)$ \\
$\geq 80$ years, $\mathrm{n}(\%)$ & $2(4)$ & $2(4)$ & $1(2)$ \\
Median & $62.26 \pm 10.80$ & $64.02 \pm 9.97$ & $59.12 \pm 10.9$ \\
Range & $30-81$ & $37-87$ & $34-85$ \\
Gender, $\mathrm{n}(\%)$ & & & \\
$\quad$ Male, $\mathrm{n}(\%)$ & $21(42)$ & $24(48)$ & $17(34)$ \\
Female, $\mathrm{n}(\%)$ & $29(58)$ & $27(52)$ & $33(66)$ \\
\hline
\end{tabular}

\section{Effect of 3 monotherapies in glycemic concentration}

Before treatment, mean fasting glucose level of groups treated with sulfonylurea and metformin was not significantly different, the mean glucose level of sitagliptin group was higher than two others groups ( $p$ values were 0.026 and 0.0003 , respectively), although patients in three groups were randomly chosen.

In all three groups, the glycemic level of all 3 time points after treatment was significantly lower than before treatment $(p<0.001)$. In the sulfonylurea and sitagliptin groups, the mean glycemic levels got the target at the month $6^{\text {th }}$, and still maintained to the month $12^{\text {th }}$ ( $p$ value of glycemic level of sulfonylurea and sitagliptin at month $6^{\text {th }}$ vs. month $12^{\text {th }}$ was 0.716 and 0.773 , respectively). Except the metformin group, at the month of $12^{\text {th }}$, the mean glycemic level had the increasing trend $(p=0.005)$ (Table 2).

Table 2: Comparison of effect on glycemic concentration of three groups before and after treatment

\begin{tabular}{|c|c|c|c|}
\hline Variables & Sulfonylurea group $^{a}$ & Metformin group & Sitagliptin group $^{c}$ \\
\hline Before treatment ${ }^{1}$ & $8.64 \pm 1.98$ & $8.39 \pm 1.72$ & $10.34 \pm 3.16$ \\
\hline$p$-values & \multicolumn{3}{|c|}{$p_{a b}=0.364 ; p_{a c}=0.026 ; p_{b c}=0.0003$} \\
\hline After 3 months treatment ${ }^{2}$ & $6.51 \pm 0.69$ & $6.53 \pm 0.84$ & $6.83 \pm 1.45$ \\
\hline p-values & \multicolumn{3}{|c|}{$\mathrm{p}_{\mathrm{ab}}=0.907 ; \mathrm{p}_{\mathrm{ac}}=0.1717 ; \mathrm{p}_{\mathrm{bc}}=0.1803 ;$} \\
\hline After 6 months treatment ${ }^{3}$ & $6.45 \pm 0.65$ & $6.34 \pm 0.59$ & $6.23 \pm 0.64$ \\
\hline$p$-values & \multicolumn{3}{|c|}{$p_{a b}=0.3745 ; p_{a c}=0.1116 ; p_{b c}=0.3565$} \\
\hline After 12 months treatment ${ }^{4}$ & $6.4 \pm 0.92$ & $6.81 \pm 1.14$ & $6.26 \pm 0.88$ \\
\hline$p$-values & \multicolumn{3}{|c|}{$\mathrm{p}_{\mathrm{ab}}=0.0436 ; \mathrm{p}_{\mathrm{ac}}=0.4585 ; \mathrm{p}_{\mathrm{bc}}=0.0113$} \\
\hline $\mathrm{p}$-value & $p_{12 a}=0.000$ & $\mathrm{p}_{12 \mathrm{~b}}=0.000$ & $p_{12 c}=0.000$ \\
\hline & $\mathrm{p}_{13 \mathrm{a}}=0.000$ & $\mathrm{p}_{13 \mathrm{~b}}=0.000$ & $\mathrm{p}_{13 \mathrm{c}}=0.000$ \\
\hline & $p_{14 a}=0.000$ & $\mathrm{p}_{14 \mathrm{~b}}=0.000$ & $p_{14 c}=0000$ \\
\hline & $\mathrm{p}_{23 \mathrm{a}}=0.515$ & $\mathrm{p}_{23 \mathrm{~b}}=0.062$ & $\mathrm{p}_{23 \mathrm{c}}=0.048$ \\
\hline & $\mathrm{p}_{24 \mathrm{a}}=0.458$ & $\mathrm{p}_{24 \mathrm{~b}}=0.100$ & $\mathrm{p}_{24 \mathrm{c}}=0.013$ \\
\hline & $\mathrm{p}_{34 \mathrm{a}}=0.716$ & $\mathrm{p}_{34 \mathrm{~b}}=0.0054$ & $\mathrm{p}_{34 \mathrm{c}}=0.7731$ \\
\hline
\end{tabular}




\section{control}

\section{Effect of 3 monotherapies in glycemic}

Before treatment, most patients had poor glucose control (Figure 1).

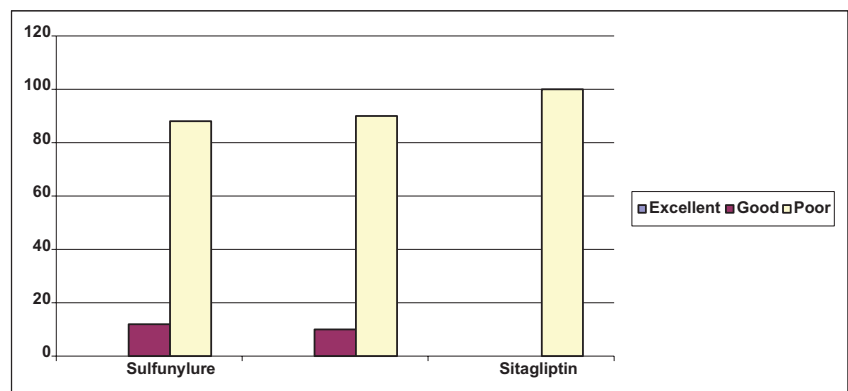

Figure 1: The rate of glycemic control of 3 drugs before treatment (\%)

After 3 months of treatment, the glucose control at excellent, good, and poor levels is $30 \%, 54 \%$, and $16 \%$, respectively, in sulfonylurea group; $30 \%, 50 \%$, and $16 \%$ in metformin group, and $22 \%, 42 \%$, and $36 \%$ in sitagliptin group (Figure 2).

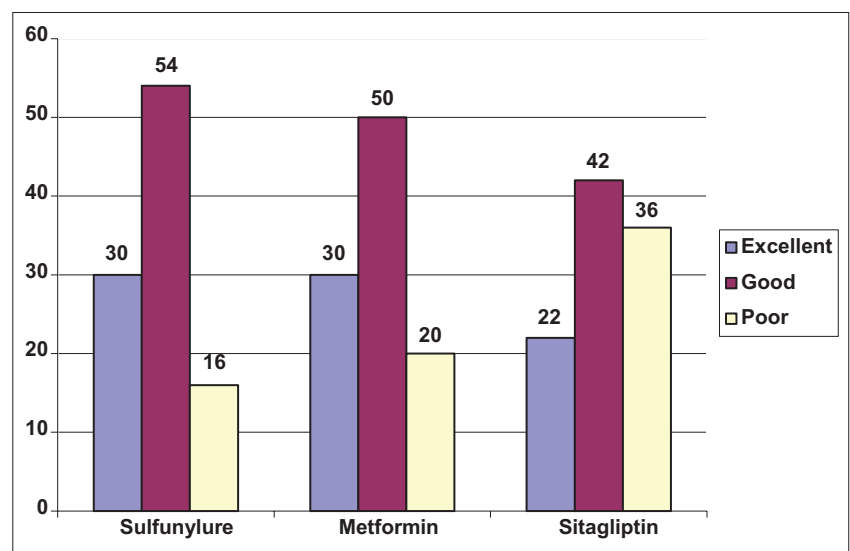

Figure 2: The rate of glycemic control of 3 drugs after treatment 3 months (\%)

After 6 months of treatment, the glucose control excellent level of sitagliptin group get the highest rate $(48 \%)$ and the smallest rate of poor glucose control $(8 \%)$. Sulfonylurea group had the highest rate of poor glucose control (14\%) (Figure 3).

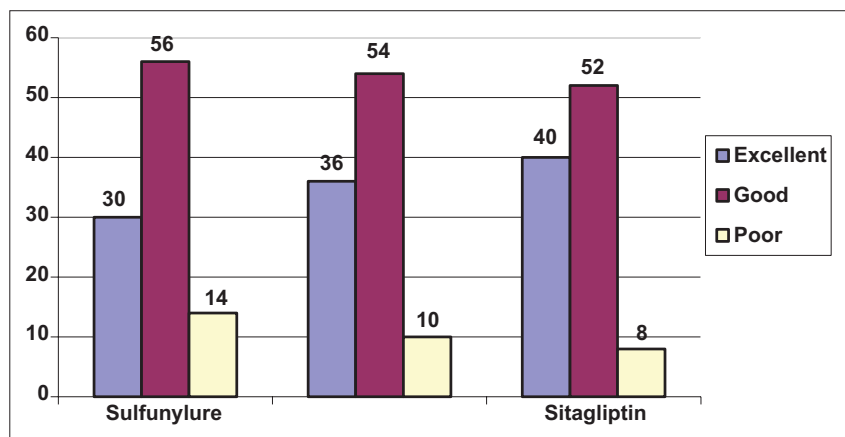

Figure 3: The rate of glycemic control of 3 drugs after treatment 6 months (\%)

After 12 months of treatment, sitagliptin group still had the highest rate of glucose control $(52 \%)$. Metformin group had the highest rate of poor glucose control (36\%) (Figure 4).

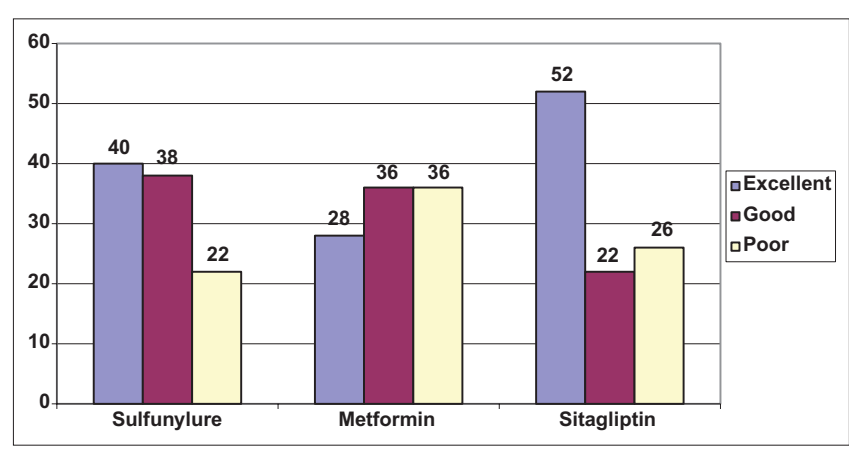

Figure 4: The rate of glycemic control of 3 drugs after treatment 12 months (\%)

\section{Effect of 3 monotherapies on HbA1c level}

At the starting of the research, $\mathrm{HbA} 1 \mathrm{c}$ level of three groups was different $\left(p_{\text {all }}<0.05\right)$. Sitagliptin group had the highest mean $\mathrm{HbA} 1 \mathrm{c}$ $(9.1 \%)$ ( $p$ values of sitagliptin group vs. metformin group and sulfonylurea group were 0.000 and 0.014 , respectively).

After treatment, HbA1c level of all three groups was different from before treatment ( $p$ values of sulfonylurea group at the month $3^{\text {rd }}, 6^{\text {th }}$, and $12^{\text {th }}$ vs. before treatment were $0.006,0.021$, and 0.001 , respectively; all $\mathrm{p}$ values of metformin group at the month $3^{\text {rd }}, 6^{\text {th }}$, and $12^{\text {th }}$ vs. before treatment were below 0.001 ; all $p$ values of sitagliptin group at the month $3^{\text {rd }}, 6^{\text {th }}$, and $12^{\text {th }}$ vs. before treatment were below 0.001).

After treatment 6 months, HbA1c of sitagliptin group was the smallest ( $p$ values of sitagliptin group vs. sulfonylurea and metformin groups were 0.007 and 0.001 , respectively) (Figure 5).

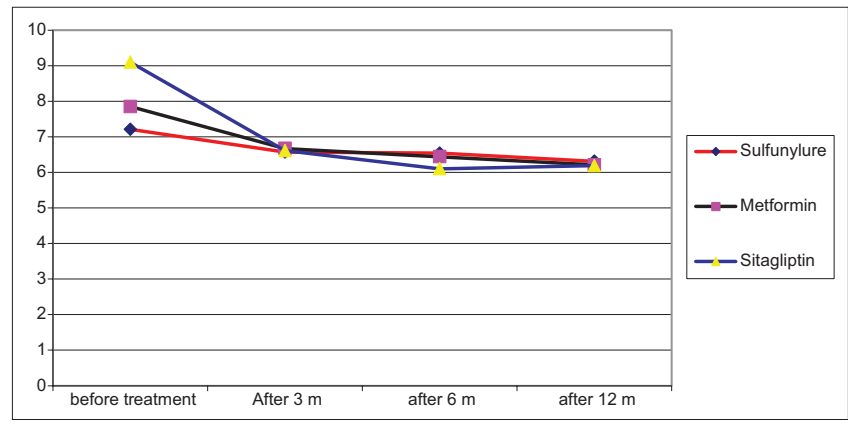

Figure 5: The effect of 3 monotherapies on glycated hemoglobin level before and 3, 6, and 12 months after treatment

\section{control}

\section{Effect of 3 monotherapies on HbA1c}

After treatment of 3, 6, and 12 months, the rates of excellent $\mathrm{HbA} 1 \mathrm{c}$ control of all three groups increased. After 12 months, sitagliptin had the highest rate. The rate of poor control of metformin and sitagliptin groups had increasing incident. The control levels of sitagliptin after treatment 6 and 12 months were the bests ( 80 and $82 \%$ ) (Table 3). 
Table 3: The HbA1c control level before and after treatment

\begin{tabular}{|c|c|c|c|c|c|c|}
\hline \multirow[t]{2}{*}{ Control level } & \multicolumn{2}{|c|}{ Sulfonylurea ${ }^{a}$} & \multicolumn{2}{|c|}{ Metformin $^{b}$} & \multicolumn{2}{|c|}{ Sitagliptin $^{c}$} \\
\hline & $\mathrm{n}$ & $\%$ & $\mathrm{n}$ & $\%$ & $\mathrm{n}$ & $\%$ \\
\hline \multicolumn{7}{|c|}{ Before treatment } \\
\hline Excellent & 17 & 34 & 0 & 0 & 1 & 2 \\
\hline Good & 17 & 34 & 25 & 50 & 9 & 18 \\
\hline Poor & 16 & 32 & 25 & 50 & 40 & 80 \\
\hline \multicolumn{7}{|c|}{ After treatment 3 months } \\
\hline Excellent & 23 & 46 & 20 & 40 & 18 & 36 \\
\hline Good & 19 & 38 & 23 & 46 & 29 & 58 \\
\hline Poor & 8 & 16 & 7 & 14 & 3 & 6 \\
\hline \multicolumn{7}{|c|}{ After treatment 6 months } \\
\hline Excellent & 24 & 48 & 26 & 52 & 40 & 80 \\
\hline Good & 18 & 36 & 23 & 46 & 10 & 20 \\
\hline Poor & 8 & 16 & 1 & 2 & 0 & 0 \\
\hline \multicolumn{7}{|c|}{ After treatment 12 months } \\
\hline Excellent & 31 & 62 & 36 & 72 & 41 & 82 \\
\hline Good & 13 & 26 & 11 & 22 & 5 & 10 \\
\hline Poor & 6 & 12 & 3 & 6 & 4 & 8 \\
\hline
\end{tabular}

\section{Discussion}

Regular monitoring blood glucose and $\mathrm{HbA} 1 \mathrm{c}$ could not only provide the doctor the data to estimate the effect of lowering medication but also control the results of medication at the best target as recommend to reduce complication. With the newly diagnosed, many evidences had proven that only treating by changing the diet could be inefficient as monotherapy by drug in insulin - independent diabetes patients [12]. Changing the diet can be difficult to get the treatment target. However, when combining with monotherapy, the fasting blood glucose decreased and got the target when followed up to 6 months [13].

When comparing the three medicine groups, the sitagliptin group had the highest proportion of patients who had excellent glucose and $\mathrm{HbA} 1 \mathrm{c}$ level after 6 and 12 months. Sitagliptin and the other drugs in the same group had been proved in increasing the effect in glycemic control. Li et al. (2014) studied on 207 patients who were treated with metformin with $\mathrm{HbA} 1 \mathrm{C}$ concentrations of $7.5-10 \%$, by adding saxagliptin or sitagliptin or vildagliptin into three groups. The results showed that after 24 weeks of treatment, the $\mathrm{HbA} 1 \mathrm{c}$ concentrations in these three groups continued to decrease by $-1.2 \%,-1.3 \%$, and $-1.1 \%$, respectively [14]. Moreover, sitagliptin stables the DPP-4 substrates, glucagon-like peptide-1, and gastric inhibitory polypeptide, both incretin hormones which act dependently to glucose to stimulate beta cells to secret insulin. Sulfonylurea stimulates directly to beta cells and not depends on glucose. Hence, for the long time, using sitagliptin can reduce stimulating the pancreatic beta cells too much. Moreover, sitagliptin also did not cause gain weight in patients while gain weight and hypoglycemia are side effects of sulfonylurea [15], [16]. Metformin decreases hepatic glucose output. Hermann et al. (1994) conducted a study comparing the efficacy of using metformin to sulfonylurea showing that the effects of glucose decrease in blood of metformin and bride are the same and among of them only metformin helped to achieve the glycemic target without gaining weight and hyperinsulinemia [13]. The evidence proved that metformin significantly reduced the risk of vascular diabetes complications is still absent [17], though the side effect of metformin was rarely. In this study, metformin also had high proportion of excellent glucose and $\mathrm{HbA} 1 \mathrm{c}$ control after treatment 12 months.

The study results showed that all three drugs using for type 2 diabetic patients were quite effective for the $1^{\text {st }}$ time; HbA1c concentration decreased, the difference was statistically significant $(p<0.05)$. The HbA1c concentration of three groups at the time of initiation and 3 months after treatment almost achieved the treatment goal according to ADA 2019 $(\mathrm{HbA} 1 \mathrm{c}<7 \%)$ [18].

Glycemic control is the main method to prevent complications. Criteria to evaluate glycemic control are $\mathrm{HbA} 1 \mathrm{c}$ proportion. According to ADA 2019, the goal of glycemic control is $\mathrm{HbA} 1 \mathrm{c}<7 \%$ [18]. HbA1c refers to hemoglobin glycated. Hemoglobin is a protein carrying the oxygen within red blood cell. The binding to glucose in bloodstream is called glycation. While glucose blood may vary from day to day depending on the diet and daily activities, the $\mathrm{HbA} 1 \mathrm{c}$ index is constant throughout the life of red blood cells, for about 120 days. HbA1c normal range is $4-6 \%$. Increasing $\mathrm{HbA} 1 \mathrm{c}$ by $1 \%$ means an increase in glucose blood value of $30 \mathrm{mg} /$ $\mathrm{dl}(\sim 1.7 \mathrm{mmol} / \mathrm{L})$. The $\mathrm{HbA} 1 \mathrm{c}$ test reflects the average glucose blood level over the past $2-3$ months. This is the best test helping doctors to monitor and to evaluate glucose blood control. HbA1c $>10 \%$ indicates the poor control of glucose blood level during the recent period. When $\mathrm{HbA} 1 \mathrm{c}$ is $<6.5 \%$ it indicates excellent glycemic control. If $\mathrm{HbA} 1 \mathrm{c}$ is not well controlled, it will significantly increase the risk of diabetes complications. According to Stratton et al. (2000), a 1\% reduction in $\mathrm{HbA} 1 \mathrm{c}$ reduces $21 \%$ risk of diabetes $(95 \%$ confidence interval from $17 \%$ to $24 \%, p<0.0001), 21 \%$ for diabetes-related deaths $(15-27 \%, p<0.0001), 14 \%$ for myocardial infraction $(8-21 \%, p<0.0001)$, and $37 \%$ for microvascular complications (33-41\%, $p<0.0001)$ [19]. Therefore, excellent control of $\mathrm{HbA} 1 \mathrm{c}$ is an important goal in the treatment of diabetes and an indispensable criterion to evaluate the effect of a hypoglycemic drug.

The limitation of this research the time that we followed patients was short. So it was difficult to assess the complications because all the patients were newly diagnosed and followed up in only 1 year. Moreover, the complications did not often appear in this period of the disease. Since, the sample had been collected and stored before tested, there could be some imprecision.

\section{Conclusion}

Significant improvement of glucose and $\mathrm{HbA} 1 \mathrm{c}$ levels was observed in all three groups. Glucose control level of group treated with sulfonylurea was markedly 
improved and the group treated with sitagliptin achieved optimal control of $\mathrm{HbA} 1 \mathrm{c}$

\section{Authors' Contributions}

Ngoc Chau Nguyen: Conceptualization, data curation, formal analysis, investigation, project administration, validation, writing - original draft preparation, writing - review \& editing; final approval of the version to be published. Quang Thuan Huynh: Conceptualization, data curation, formal analysis, investigation, project administration, writing original draft preparation, writing - review \& editing; corresponding; final approval of the version to be published. Hoai Thuong Pham; Diep Thao Pham; Thi Minh Hoang; Thi Phuong Lan Dam; Thi Hang Ho: Data Curation, investigation, methodology, writing - original draft preparation; final approval of the version to be published. Duy Quy Dang; Nhu Binh Do: Interpretation of data, methodology, writing - original draft preparation; final approval of the version to be published.

\section{Acknowledgments}

The project received financial support from the Ministry of Science and Technology, the Vietnamese government. We thank for that support.

\section{Ethical Statement}

All participants were dispensed with written informed consents, and the study was approved by the Ethical Committee of Military Medical University, Hanoi, Vietnam (No: 68/2017/QĐ-HĐĐĐ date 28 month 4 year 2017). The study was also conducted using good clinical practice following the Declaration of Helsinki.

\section{References}

1. Punthakee Z, Goldenberg R, Katz P. Definition, classification and diagnosis of diabetes, prediabetes and metabolic syndrome. Can J Diabetes. 2018;42(Suppl 1):S10-5. https://doi. org/10.1016/j.jcjd.2017.10.003 PMid:29650080

2. Ritz E, Rychlik I, Locatelli F, Halimi S. End-stage renal failure in Type 2 diabetes: A medical catastrophe of worldwide dimensions. Am J Kidney Dis. 1999;34(5):795-808. https://doi. org/10.1016/s0272-6386(99)70035-1

PMid:10561134

3. del Canizo-Gomez FJ, Moreira-Andres MN. Cardiovascular risk factors in patients with type 2 diabetes. Do we follow the guidelines? Diabetes Res Clin Pract. 2004;65(2):125-33. https:// doi.org/10.1016/j.diabres.2003.12.002

PMid:15223224

4. Garber AJ, Abrahamson MJ, Barzilay JI, Blonde L, Bloomgarden ZT, Bush MA, et al. Consensus statement by the american association of clinical endocrinologists and american college of endocrinology on the comprehensive Type 2 diabetes management algorithm--2016 executive summary. Endocr Pract. 2016;22(1):84-113. https://doi.org/10.4158/ep-2018-0108 PMid:26731084

5. Davies MJ, D'Alessio DA, Fradkin J, Kernan WN, Mathieu C, Mingrone $G$, et al. Management of hyperglycemia in Type 2 diabetes, 2018. A consensus report by the American diabetes association (ADA) and the European association for the study of diabetes (EASD). Diabetes Care. 2018;41(12):2669-701. https://doi.org/10.2337/dci18-0033

PMid:30291106

6. Chan SP, Colagiuri S. Systematic review and meta-analysis of the efficacy and hypoglycemic safety of gliclazide versus other insulinotropic agents. Diabetes Res Clin Pract. 2015;110(1):7581. https://doi.org/10.1016/j.diabres.2015.07.002 PMid:26361859

7. Khunti K, Chatterjee S, Gerstein HC, Zoungas S, Davies MJ. Do sulphonylureas still have a place in clinical practice? Lancet Diabetes Endocrinol. 2018;6(10):821-32. https://doi. org/10.1016/s2213-8587(18)30025-1

PMid:29501322

8. Nauck MA, Meier JJ, Cavender MA, Abd El Aziz M, Drucker DJ Cardiovascular actions and clinical outcomes with glucagonlike peptide-1 receptor agonists and dipeptidyl peptidase-4 inhibitors. Circulation. 2017;136(9):849-70. https://doi. org/10.1161/circulationaha.117.028136

PMid:28847797

9. World Health Organization. Type 2 Diabetes Practical Targets and Treatments 2002 (Targets for Control). Geneva: World Health Organization; 2002.

10. Alberti KG, Zimmet PZ. Definition, diagnosis and classification of diabetes mellitus and its complications. Part 1: Diagnosis and classification of diabetes mellitus provisional report of a WHO consultation. Diabetic Med. 1998;15(7):539-53. https://doi.org/10.1002/ (sici)1096-9136(199807)15:7<539::aid-dia668>3.0.co;2-s PMid:9686693

11. American Diabetes Association. 6. glycemic targets: Standards of medical care in diabetes-2020. Diabetes Care. 2020;43(Suppl 1):S66-76. https://doi.org/10.2337/dc20-s006 PMid:31862749

12. United Kingdom Prospective Diabetes Study (UKPDS). 13 Relative efficacy of randomly allocated diet, sulphonylurea, insulin, or metformin in patients with newly diagnosed noninsulin dependent diabetes followed for three years. BMJ. 1995;310(6972):83-8. https://doi.org/10.1136/bmj.310.6972.83 PMid:7833731

13. Hermann LS, Schersten B, Bitzen $P O$, Kjellstrom $T$, Lindgarde $F$, Melander A. Therapeutic comparison of metformin and sulfonylurea, alone and in various combinations. A double-blind controlled study. Diabetes Care. 1994;17(10):1100-9. https:// doi.org/10.2337/diacare.17.10.1100

PMid:7821128

14. Li CJ, Liu XJ, Bai L, Yu Q, Zhang QM, Yu P, et al. Efficacy 
and safety of vildagliptin, Saxagliptin or Sitagliptin as add-on therapy in Chinese patients with Type 2 diabetes inadequately controlled with dual combination of traditional oral hypoglycemic agents. Diabetol Metab Syndrome. 2014;6:69. https://doi. org/10.1186/1758-5996-6-69

PMid:24917890

15. Ommen ES, Xu L, O'Neill EA, Goldstein BJ, Kaufman KD, Engel SS. Comparison of treatment with sitagliptin or sulfonylurea in patients with Type 2 diabetes mellitus and mild renal impairment: A post hoc analysis of clinical trials. Diabetes Ther. 2015;6(1):29-40. https://doi.org/10.1007/ s13300-015-0098-y

PMid:25633134

16. Shankar RR, Xu L, Golm GT, O'Neill EA, Goldstein BJ, Kaufman KD, et al. A comparison of glycaemic effects of sitagliptin and sulfonylureas in elderly patients with Type 2 diabetes mellitus. Int J Clin Pract. 2015;69(6):626-31. https:// doi.org/10.1111/ijcp.12607

\section{PMid:25652751}

17. Griffin SJ, Leaver JK, Irving GJ. Impact of metformin on cardiovascular disease: A meta-analysis of randomised trials among people with Type 2 diabetes. Diabetologia. 2017;60(9):1620-9. https://doi.org/10.1007/s00125-017-4337-9 PMid:28770324

18. Aeronautical Development Agency. Standarts of medical care in diabetes. Diabetes Care. 2019;42:66.

19. Stratton IM, Adler AI, Neil HA, Matthews DR, Manley SE, Cull CA, et al. Association of glycaemia with macrovascular and microvascular complications of Type 2 diabetes (UKPDS 35): Prospective observational study. BMJ. 2000;321(7258):405-12. https://doi.org/10.1136/bmj.321.7258.405

PMid:10938048 